\title{
LEGAL ASPECTS OF MERCHANDISING IN SPORTS
}

\author{
Mario Lukinović ${ }^{5}$, Ana Opačićc ${ }^{6}$, Irena Milojević ${ }^{7}$
}

doi: $10.5937 / O d i t o r 2002063 L$

Originalni naučni rad

UDK

659:796(497.11)

\begin{abstract}
In the last thirty years, sport has undergone a significant transformation from a means of satisfying the need for physical activity, affirmation or competition with others to an extremely profitable industry. The development of sports has been favored by the development of mass media in terms of the creation of planetary sports idols. Consumers today are exposed to aggressive marketing policies, and manufacturers are trying to overcome information overload by exploiting recognizable symbols that consumers want to identify with through the emotional positioning of products. The authors point out the importance of merchandising as well as all the specificities that it manifests in its application in sports, with particular reference to the legal framework, and instruments for the further transfer of rights and protection of them.
\end{abstract}

Key words: merchandising, transfer of rights, sport, marketing, Serbia.

\section{Introduction}

The Sports Law (2016, Art. 2) tends to define sports in a comprehensive way. It defines it as a part of physical culture, without making a difference between organized and non-organized form of performing not only sports activities abut also sports agency, thus envisioning the widest range of individuals in the sports system. Sports is the means used by all natural and legal persons in order to fulfil their need for creation, affirmation, physical exercise or competing with others. Nowadays, even though this definition is still consistent, sports resemble a sort of a financial venture accelerator. Throughout times, it has undergone

\footnotetext{
${ }^{5}$ Mario Lukinovic, Ph.D., Associate Professor, Faculty of Law of the University "Union", Belgrade, Serbia, ana.galjak@gmail.com

${ }^{6}$ Ana Opacic, Ph.D., Associate Professor, Faculty of Business Studies and Law, University "Union-Nikola Tesla", Belgrade, Serbia, mario.lukinovic@ pravnifakultet.rs

7 Irena Milojevic, Researcher, Institute of applied sciences, Lomina 2, Belgrade, Serbia, i.miloje.bg@gmail.com
} 
changes, from representing a cohesion of the basic need of a man for physical activity, to an interconnected network of psychological, social, cultural, legal and medical ties. The contemporary sports seem to put an emphasis on the economic substrate, and thus this industry branch records an incredible growth. The projections speak in favour to the fact that professional sports represent 3\% of the total of the world industry (Šurbatović, 2014). In this rapidly growing market, positioning is one of the key goals of many companies. In accordance with that, the promotional activities have long stopped being the matter of choice of sports organizations, but have become a necessary strategic direction in realization of sports goals (Dobrijević, Ilić, 2019). The development and changes within sports-technological and business-managerial segments of sports organizations are changing their business philosophies to the root. Thanks to its marketing potential, sports have become an industry. The consumers are nowadays exposed to agressive marketing politics, and thus producers are attempting to surpass the information overload by exploiting recognizable symbols with which the consumers easily identify themselves, and this is being done through emotional possitioning of the product. Hand-in-hand with music, fashion and film, sports is an absolutely inviolable medium for transmitting wished information to the customers. However, due to high competition, the producers have to maximize their investment and seek new ways of approaching to the customers. They attempt to emotially tie a consumer to a product through emotional positioning of the product(Perić, Vitezić, Badurina, 2019), by transmitting a psychological message about an "additional purpose" of the said product. It turned out that this emotional factor in sports, as well as the need for identifying with the favourite club or sportsman, represent a sort of a mine that often brings enormous earnings to the individual engaged in sports, which conditioned the need for taking a closer look at this phenomenon.

\section{Basic conceptual definition of the term merchandising}

Loyalty of sports fans is more pronounced than that of other users, due to their special emotional attachment, and the (customer churn) (Jovanović, Milenković \& Damnjanović), is the least present. Company menagers during proces selecting business strategies, whether market penetration, market development, product development or diversification strategies (Ćurčić, Kostić \& Arapović, 2018), pay particular attention to marketing, in order to target products and services to consumers, consumer desires to bidders (Ćorić, 2019). Although sports marketing is still viewed through aspects of marketing of sports organizations and marketing of sports-related products and services (Gašović, Vukajlovic, Curčić \& Zivković), new modalities of consumer access to the market are becoming more and more pronounced. 
The term merchandising is primarily used in marketing in order to name strivings of the companies for the purpose of improving rentability of their sales network. Merchandising does not have a long tradition. The roots of its origin belong to the US. Its emergence is closely connected with the increase in numbers of products and the creation of big sales objects, and primarily refers to the display methods and product representation in order to increase rentability. In the narrow sense, it implies all activities within the sales space linked to the product itself, such as product positioning and display, promotional activities inside the sales space with the goal of imrpoving the sales, etc. Besides its primary use, merchandising refers to placement on the market the products that contain fictional characters, real persons, personal names, names of sports clubs, etc., or products that use the names and characters of fictional or famous people and elements of art pieces in order to promote and sell the products or services, and all with the goal of exploiting the recognizability of the symbol they represent and with which the consumers wish to indentify themselves with (AIPPI, 1995). Merchandising actively contributes to the originality of sales through emotional identification and product presentation, and it combines different material and non-material goods. The indispensible substrate of merchandising is the active building of the trade mark, since it is exacly the easiest way for emotionally reaching the customer and directing the said customer towards a certain product. The elements used in merchandising might be legally protected based on the Law on Trademarks, Law on Autorship, Law on Unfair Competition, and in some countries, even by the act of preventing "representation of goods of lower quality as the goods of a famous producer". In legal sense, merchandising is used for defining the rights to using characters or personalities for commercial purposes (Funk, Pizzo, Baker, 2018). Merchandising often also refers to additional use of intellectual property which generated revenue often surpasses the revenue aquired through its primary use. The basic form of such transfer of rights is the licence that is characterized by the fact that a certain form of the intellectual property, and most often the brand, is being leased for use on the products that are different from the products for which the said brand was previously created and registered. The contemporary mass media are not only transmitting information, but have, to the contrary, become the main actors of marketing positioning (Vidović, \& Jugović, 2014). Nowadays, sports objects are more resembling to billboards than to places where sports fans meet. The emission rights or TV rights for certain maches, championships and even the Olympics represent an extremely important segment. The ammounts that follow the contracts signed when leasing such rights sometimes surpass the GDP of certain countries. 
For the purpose of illustration, the emission rights for the organizers of the Olympics have increased with the growth of popularity of this sporting event. For example, it varied from 1,6 million USD (Tokyo, 1964), to 286,6 million USD (Los Angeles, 1984), million and a half USD (Athens, 2004), to 2,5 million USD (London, 2012). This money is being given to organizers of the matches (clubs, cities, states, international sports federations, International Olympic Committee - IOC, etc.). All great world companies strive towards sponsoring the Olympics. In this way, they gain global promotion, which is the 'privilege' of the chosen ones, the greatest ones. The Coca-Cola Company, which has a contract with the IOC until 2020, is one of eleven multinational companies (Coca-Cola, Visa, Acer, Atos, Ge, McDonald's, Panasonic, Omega, Samsung), that have entered into a long-term Olympic engagement.

The image of a club is the representation of itself, its sporting successes, as well as its positioning in the minds of people of its narrower and broader surroundings. From the marketing aspect, image of a sports organization or a top athlete might be transferred to some profit organization that wishes to position their products better on the market. In the same sense, through the image of a sports organization, certain products of the profit organization might be promoted (Milojević, 2003). Building an image of a club is of a crucial role that, besides the active creation of a recognizable brand, also enables a great interest of sponsors that wish to join in with their financial resources, thus ensuring that their product gets the emotional connection implied by merchandising. On the other hand, sports fans decide through identification for a wide pallete of products and services offered by their favorite club or a brand. Sports objects or arenas where contemporary sporting events take place are commercialized to the extreme limits, and thus nowadays you might identify from the birth with baby supplies branded by the mark of your parents' favorite clubs, sports jerseys, different souvenirs, sheets and even cars signed by a certain player. In the broadest sense, these souvenirs that represent a brand themselves, have become a powerful means for acquiring funds that are later invested in facilitating transfer of players, especially in the world of football. It is even possible to lease sports objects to natural persons that are ready to pay a bigger amount of money(Lamont, Kennelly, 2019). Branding sports objects is nowadays a reality. Sports objects and arenas world-wide, but also in our country, are more and more often carrying the name of their sponsors. The Munich Arena, carrying the name "Allianz Arena", is in fact a great example of the said practice. Its construction costed 340 million EUR, and the sponsor, that comes from the field of provision of financial services and insurance - the Allianz Group, has signed a contract and thus acquired the rights to presenting its own name within the name of the said arena for the period of next 30 years. We are witnessing that certain fields of sports not only provide a possibility for 
earning, but also represent a possibility for exquisite business ventures that bring along high profit, which has conditioned the need for development of different levels of management in sports. The bigger the profit, the investment is more profitable, which leads to the conclusion that making a profit is actually the mover and the motive of entrepreneurship in sports, so that the said products and programs have the same value on the market as others.

\section{The rights of using popular characteris for commercial purposes (character merchandising)}

This right might be defined as secondary exploitation of personal traits of fiction or real characters by their creator or owner whose character on the name is being used or, on the other hand, by individuals to whom the given rights are passed on, and refer to the use of the beforementioned characters in comparison to other types of goods or services with the goal of attracting consumers. The rights of use of popular characters for commercial purposes are most often used in the following two manners: sometimes the elements of merchandising make the product itself or are applied to the said product, and sometimes they are used exclusively as a propaganda element that, in no other way, is included in the product(Marinković, Milošević-Stolić i Ivanova, 2019).

The use of popular characters for commercial purpose came to life during the thirties of the 20th century in the studio of the Walt Disney Company, when Kay Kamen founded a separate department for additional commercial exploitation of the animated characters of the said company.8 Even though similar ideas existed even before, envisaged in the Michelin man and numerous other fictional characters used on packaging in order to popularize a product on the market, such approach represented a pioneering venture. To the surprise of numerous sceptics, this department of the Walt Disney Company placed numerous licenses for production and distribution of trading goods branded by the image of characters such as Mickey Mouse, Minnie Mouse, Donald the Duck, etc. on the market. A big momentum for character merchandising occurred in the fifties of the 20th century, when numerous personalities from the world of show business, film and politics started using their names and faces on clothes, thus commercialising their popularity. This contemporary phenomenon is the source of enormous financial means. Besides animated

\footnotetext{
${ }^{8}$ The Walt Disney Company sold in 1929 the rights to use the image of Mickey Mouse on school writing boards. Shortly afterwards begun a great campaign of merchandising and licencing, after which the image of Mickey Mouse appeared on a great number of different objects (from underwear to jewellery). When explaining their intentions, one of the Disney company members stated the following: "Selling dolls with Mickey's face to any member of a household provides a daily comamercial for our cartoons within the said household, and all members of that family will constantly have Mickey before their eyes."
} 
characters, a significant source for character merchandising represent characters from novels (such as Harry Potter) or cartoons (Snoopy), as well as successful movies. Sporting events (national, regional and world championships, Olympics, etc) and clubs represent an important segment of commercialization of popular characters. Nike Company is famous for having a special sporting line characterized by the silhouette of the famous basketball player Michael Jordan. A good indicator of the range of character merchandising are also two legal cases. Namely, sneakers with the logo and the name that significantly resembles to the planetary famous line of the Nike Company appeared on the Chinese market(Rowe, Karg, Sherry, 2019). The said new brand on the Chinese market appeared under the name Qiaodan, that could be approximately transcribed as "Jiodan", which is exactly how the Chinese interpret the last name of the best basketball player of all times. Consequently, Nike sued for copyright infringement and demanded the closure of the said company, but the Beijing court did not share the opinion. In the reasoning of the verdict it is stated that the lawsuit had no basis, and that Qiaodan does not necessarily mean that the name Michael Jordan was chosen, that the said word does not mean anything in English, and that the logo of the said Chinese company, even though it resembles to the famous brand's silhouette, is unique (Wen-yu Young, 2016). The Nike Company filed a total of ten lawsuits, and the basketball player himself joined the fight for the protection of his name. The situation turned into an interesting direction when the Chinese sporting brand Qiaodan sued the basketball player himself for intentional misguidance of consumers regarding the outcome of the legal battle, thus demanding compensation amounting to 1,1 million juans, which is about 180.000 USD.

The second case that put the famous basketball player into the spotlight is the lawsuit for copyrights infringement of the photographer that stated that Nike exploits the logo of the popular "Air Jordan" brand without authorization, given that he himself photographed the famous basketball player in the said position and that the negatives of the same photograph were later, without authorization, used for the creation of the nowadays recognizable Jumpman logo. The photographer Rentmeester states that "the jumping man" was stolen from the photograph he took for Life magazine over thirty years ago. As stated in his lawsuit, he photographed for Life magazine Jordan in 1984, while he was still a student at the North Carolina University, slam dunking with his legs spread, and Nike paid him a compensation for the use of the said negative. Soon enough, Nike shot their own photograph and stopped using the original one. After another complaint of the photographer stating that his work was once again used without authorization and that the new photograph resembles too much to the original photograph, the Nike Company paid the said photographer another compensation in the amount of 15000 USD in order to retain rights to the use 
of the said photograph. The complaint does not mention the existence of a written contract nor attaches the said contract, but states that there was an agreement regarding the two-year time limit, as well as a spatial limit stating that the said photograph was to be used only within the territory of North America. Thirty years and a few billion dollars later, the Nike Company still uses the same logo created in 1987, while the photographer Renmeester still demands a financial compensation, stating that the photograph taken by Nike does not contain the basic substrate of originality in order to enjoy legal authorship rights, but to the contrary, having in mind the "obvious conceptual similarities" that both photographs have, it is clear that in this case, we are speaking of illegal use and copyright infringement (Rentmeester v. Nike). The court council concluded that Nike did not commit copyright infringement, providing an explanation that the legal authorship protection does not apply to a certain pose stricken in a photograph, but only in the way a certain pose is expressed, the lights, the camera angle, the speed of lens closure, etc. The council stressed that the photograph enjoys a legal authorship protection that is limited only to specificity of elements that make the said photograph, and thus that Jumpman logo is in essence not similar to Remsteer's photograph (Rentmeester v. Nike, 7-9).

The right of use of popular character for commercial purposes is most often manifested in two ways: sometimes the elements of merchandising make the product itself or are applied to the said product, and sometimes they are used only as a propaganda element that is not in any way included in the product. The use of real personalities known to a wider public, that is, personality merchandising, is also called reputation merchandising. The use of image of real personalities is founded in the attitudes of a significant segment of consumers for whom the product itself is not of the primary importance, but the name or the image "carried" by the said product, and that represent the product's main marketing tool. The use of characteristics of famous personalities is especially widespread in the domain of the entertainment industry (film, television, sport, etc.). The world of contemporary communications offers a wide range of possibilities for processing original works, and thus many film adaptations of literary works are far more famous that their original works. The legal protection can be enforced through a trade mark, authorship rights or through stipulations of the unfair competition.

\section{Merchandising trade marks}

A trade mark is the right that protects the stamp that is in traffic used for differentiating goods, that is, services of a natural or a legal person, for the same of similar goods, that is, services provided by some other natural or legal person (Law on Trademarks, 2009, Art 1. Par.2. ). The protection of character 
on the basis of trade mark rights does not demand originality, unlike legal authorship protection that asks for the originality of the work. Moreover, when proving the trade mark copyright infringement, the owner of the rights does not have to prove that the sued entity had access to the character as demanded by the authorship rights, but it is enough proving that the use was conducted without permission of the character protected by the trade mark. The duration of a trade mark is temporally unlimited, since they last as long as the protection is being prolonged with the competent authority. Every change in the appearance of the character, however, might harm the original trade mark protection, and thus it often asks for a mandatory supplemental registration (of the new trademark with the said changes) in order to protect the contemporary appearance of the character from the unwanted abuse.

Previous judicial practice in the countries practicing Anglo-Saxon law regarding the litigations for unlawful use of characters by third parties treated see, upon proving a trade mark infringement, the process of proving of the likelihood of confusion as a key point. The said practice demanded proving the fact that the consumers were misled or deceived regarding the origin of the products marked by the character protected by the trade mark. Hence, Elvis Presley Enterprises Inc. Company, the holder of rights linked to the intellectual property of the deceased singer, initiated a lawsuit against a trader Sid Shaw, who sold memorabilia containing the name and the image of Elvis Presley on the streets of London (Peluso, Rizzo, Pino, 2019). The court has, starting from the stance that, in accordance with the English law, personal rights cannot be protected by a trade mark, and thus the only role of a trademark is the differentiation of products on the market (Vukša, Anđelić i Milojević, 2020) from similar products of other producers, made a decision that the customers were not mislead regarding the origin of the said goods. In order to fulfill the conditions for legal protection, there must be a connection between a trade mark and its holder. In the reasoning of the court decision was stated that Elvis Presley, if he were alive, would not be able to prevent his fans from naming their children or house pets Elvis or Elvis Presley, or even tattoo his image on their bodies. The judge stated that even the consumers that bought the goods from Sid Shaw did not believe that it really originated from Graceland (Elvis's memorial center) or that they were licensed by the authorized holder of rights. This court decision swung a hard hit to the unauthorized use of characters by third parties, and thus as one offered modality for the protection of rights of famous personalities and authors of popular fictional characters appeared a trade mark - Official Licensed Goods in order to stress the authentic origin of the product in traffic. 
Moreover, the litigation led in the US between the producer of dolls with the image of Barbie and the record label MCA Records Company for the Barbie trade mark infringement (based on the federal law on trade marks - Lanham Act) and the trade mark dilution (by breaking the law proscribed by The Trademark Dilution Act) stressed the contemporary attitudes of the legal practice of the trade mark protection of merchandising. The Court of Appeals (The 9 - U.S. Circuit Court of Appeals) confirmed the previously made decision of the District Court of the Central California District of California that the said complaint is unfounded. In the reasoning of the court's decision, the Court called upon the stances brought up in the court ruling regarding the complaint of the famous actress and dances Ginger Rogers to the title of the Frederick Fellini's movie "Ginger and Fred" that, as she believed, led to a wrong impression that she was linked with the said movie. The mentioned court ruling rejected the complaint of the actress Ginger Rogers, given that the said title did not cause the trade mark infringement, except in cases when there was in a direct artistic connection with the fundamental work or if it was the case of a literal deception in relation to the source. Following the beforementioned court ruling, the Court believed that the title was in a fundamental relation to the stated work, and that the use of the trade mark by the MCA Records was diluted. However, in the present case, it was the case of an exception representing a non-commercial use in trade mark dilution. The Court stated that, even though the MCA Records uses a registered trade mark in order to sell copies of a song, the said use is not commercial, since the song is a social commentary of culture values represented by the Barbie doll (Zlatović, 2010, 171).

\section{Merchandising of sporting objects}

Products of sport industry does not anymore include just sports, recreation and fitness activities, material goods and services related to sports, recreation and fitness (Savić, Ranđelović, Stojanović, Stanković \& Šiljak, 2017). The phenomenon that has recently been taking a more and more significant place within the world of merchandising, thanks to, above all, enormous amounts of money that are being invested in it, but also the attention that it causes within the public, is the leasing of rights to naming sporting objects to the sponsor. For example, even though football stadiums, as places were football matches are held, have primacy, sporting objects which host baseball, basketball, hockey and other sports matches also follow that trend. Leasing the rights to naming sporting objects to sponsors emerged in the US, and that idea of new sources of finance spread fast on a global level. Sports and entertainment (including music and film) are the most popular forms of social activities that are followed by billions of people world-wide. Because of that, the majority of big global 
producers and service providers are turning their branding strategies to this type of branding. Sponsors that allocate funds in order for a stadium to carry the name of their company or a trade mark, besides direct marketing, also wish to achieve an additional synergy, expressed through the character of the team played on the said sporting object. The sponsors wish their name to be carried by the stadiums on which plays a team adorned by the traits of their products or the traits they wish their consumers to believe that that their products have. Moreover, they count on the fact that ensuring big additional material funds for the functioning of the team causes gratitude and respect among numerous sympathizers and fans of the sponsored club, since in such a way, bigger funds are ensured for procurement of better and more quality players and coaches. Such contracts are usually concluded for a longer period of time, and sometimes even include other forms of merchandising - above all, writing the names of the sponsors on the sportsmen jerseys. The attention and media promotion acquired through such contracts are huge, and represent one of basic motives for extremely high financial investments of the sponsors. Such example can also be found in our country. Namely, in February 2012, eight years after the construction of the multimedia sporting object "Arena" in Belgrade, that is owned by the city, after the announced competition, the said object carried the name of a sponsor for five years. After the expiration of the contract, the sporting object changed its name and now carries the name of the new sponsor.

We are witnessing that also numerous catering facilities worldwide carry the names of characters from novels, movies and even musical tracks. Before general recognition of the capacity of merchandising through naming the catering facilities by the names of characters, such practice was almost usual and usually happened without the consent of the holders of the ownership rights to the said works from which the given names of characters and the names of the objects named by the names of the said characters emerged. The enormous financial success of the transmission of fictional characters into the real world, as well as general information, caused the emergence of first judicial proceedings in this field.

Likewise, the lovers of the art, as well as tourists worldwide, when visiting museums, exhibitions, art galleries, cultural and music manifestations, which to buy shirts, scarves, mugs, jewellery and other objects, in memory. The objects decorated by the artworks of Gustav Clint, Van Gogh, Andy Warhol, and the names and symbols of EXIT, the Night of the Museum, the Madam Tussauds Museum, etc. can be found everywhere. In such a way, besides gaining an additional source of revenue, the visibility and popularity of the artist, the gallery or the museum are evidently improved. 
Merchandising is most often linked to commercial abuse of symbols used for marking products. However, as previously stated, besides direct material revenues, it also provides numerous other benefits.

\section{Conclusion}

In the recent years, sport has gone through significant changes, from the essential need for physical activity of an individual, social, psychological and medical aspect, to one of the most profitable fields of economy. What makes sports such a successful industry is the capacity to, besides having a central activity that is in a direct link to the mere physical activity (selling tickets for sporting events), generate enormous financial means through sponsorship and various types of leasing the rights. Exactly this accessory revenue exceeds multiple times the basic revenue that is acquired through a direct realization of sporting activities. Multimillion transfers of players are paid in a short period of time though selling different objects that carry their name and insignia. Sporting arenas are not anymore only the temples of sports, but resemble to a sort of sanctuaries of certain brands. Leasing the rights to sponsors in order to have them completely identify with a certain club provide them with a possibility to absorb their positive image and to approach their business and make it available to a wider circle of people. This connection also carries along the need for preservation of the good image that might be threatened by negative acts of the sportsmen in question. It might reflect to crumbling of the dignity of the said brand and the general sponsor's stock price decline as well, which might lead to his retreat, termination of the contract on leasing the rights, compensation of damages, etc. With the development of mass media in the global society, they become not only the source of information, but they also influence the creation of life and cultural styles and attitudes of an individual, and represent a powerful tool in the hands of merchandising as well. Mass media also influence the development of marketing, the increase in consumption, as well as public opinion. The rise of mass media has led to population of sports to the global scale. Sports news and sports content as most followed on television, but the Internet, mobile applications, social networks and specialized sporting programs as well. The mass media have an exquisite psychological, propaganda and technological power, and hand-in-hand with sports, they spread their influence on a global plan. The media are becoming a global stadium of the contemporary sports (Stanković, 2017). The mass media are the ones that are creating the sports idols, they are a powerful tool for ensuring promotion, and thus also money. Sponsors are racing exactly because of the possibility of imposing themselves to the viewers not only on some sporting competition, but also in the comfort of their homes, and insensibly make them identify with a brand they support. 
Brand is a contemporary phenomenon. The consumers are less and less buying a product or a service, and are more buying a brand. They help customers choose, and provide companies with a better position on the market. In order to build a successful brand, much time or a lot of money is need, and often both. The intellectual property rights enable legal protection of its key elements: the trade mark, the design, authorship and familiar laws, geographic indications of origins and patents. Without the intellectual property rights, the life span of successful brands would be limited to months. It provides legal protection, and thus enables preservation of its uniqueness and all the specialities that differentiate it from the variety of similar products or services, thus making it recognizable on the market and enabling its further improvement and economic exploitation through further lease of rights to the use of its different segments (Milovanović \& Lukinović, 2017).

Unauthorized reproduction of products causes enormous loss to the legal holders of rights. The loss is not only reflected directly, as reduction of the scope of salles, but even greater damage emerges from undermining of the acquired image of the market, the loss of product exclusivity, as well as the creation of the atmosphere of distrust into the credibility of the said product. The protection of intellectual property is imagined as means for encouraging creative work, transfer of technology, industrialization, investment and fair trade. In this work, the authors presented through different judicial cases that the industrial property cannot adequately respond to all demands of the market, that creating planetary sports idols does not also imply the possibility of protection for the unauthorised use of character or name by the third party. On the other hand, the case Jordan v. Quordain sends strong messages regarding the need for appreciation of different intellectual rights and industrial property protection, as well as the need for ensuring trade mark protection even in the phase of brand creation. We believe that, besides the fact that merchandising has certain specifics that above all refer to products and services that are different from the ones usually used and/or in relation to them, it in essence represents a certain form of licencing. Given that in contemporary legal systems there are not any special legal solution that refers to the protection of merchandising, within our law, provisions stipulated by the Law on Trademarks and Familiar Laws should be applied, depending on the object of the law on lease and the circumstances of the case. In the practice, trade mark most often protects personal names of sportsmen, names of clubs, coats of arms of sports associations, two-dimensional appearance of the mascot of the club or its fans. The registration of the trade mark itself is not obligatory, but it is a possibility that enables the absence of generating costs in the name of litigations, while on the other hand enables multiplication of the invested money through further 
lease of rights through license, franchise and other contractual modalities that enable further brand exploitation.

\section{Literature}

1. AIPPI, Legal aspects of merchandising (Question Q 129). 1995. XXXVI Congress de Montreal.

2. Ćorić N. 2019. Korporativna komunikacija. Synopsis, Zagreb - Sarajevo Mostar.

3. Ćurčić M., R. Kostić, i T. Arapović. 2018. Planiranje i kontrola kao funkcije menadžmenta preduzeća. Oditor 4, (1): 94-103.

4. Dobrijević S., i V. Ilić. 2019. Antropomorfološke varijable kao prediktori tranzitne brzine kod fizički aktivnih žena. Godišnjak Fakulteta sporta i fizičkog vaspitanja (24): 18-28..

5. Funk D.C., A.D. Pizzo, B.J. Baker. 2018. eSport management: Embracing eSport education and research opportunities. Sport Management Review 21, (1): 7-13

6. Gašović M. Đ. Vukajlović, N.Ćurčić, M. Živković. 2018. FACTA UNIVERSITATIS Series: Physical Education and Sport 16, (1): 167-179.

7. Jovanović D., N. Milenković, i R. Damnjanović. 2017. Ocenjivanje i predviđanje potreba potrošača. Oditor 3, (1): 70-79.

8. Lamont M., M. Kennelly. 2019. Sporting hyperchallenges: Health, social, and fiscal implications. Sport Management Review 22, (1): 68-79

9. Law on Authorship and Familiar Rights, The Official Gazette of the Republic of Serbia, no.104/2009, 99/2011, 119/2012 and 29/2016- the decision of the Constitutional Court.

10. Law on Trademarks, The Official Gazette of the Republic of Serbia, no. 104/2009, 10/2013 and 44/2018 - state law.

11. Marinković M., J. Milošević-Stolić, i B. Ivanova. 2019. Andragoška podrška razvoju kompetencija kadeta vojne akademije u oblasti fizičkog vaspitanja u cilju postizanja njihovog efikasnijeg opšteg uspeha studiranja. Vojno delo 71, (7): 226-233.

12. Milovanović S., M.Lukinović. 2017. Nacionalno brendiranje. Službeni glasnik, Beograd.

13. Peluso A.M., C. Rizzo,G. Pino. 2019. Controversial sports sponsorships: Effects of sponsor moral appropriateness and self-team connection on sponsored teams and external benefit perceptions. Journal of Business Research 98, 339-351

14. Perić M., V. Vitezić, J.Đ. Badurina. 2019. Business models for active outdoor sport event tourism experiences. Tourism Management Perspectives 32, 100561 
15. Rowe K., A. Karg, E. Sherry. 2019. Community-oriented practice: Examining corporate social responsibility and development activities in professional sport. Sport Management Review 22, (3): 363-378

16. Savić Z., N. Ranđelović, N. Stojanović, V. Stanković, V. Šiljak. 2017. The Sports Industry and Achieving Top Sports Results. FACTA UNIVERSITATIS Series: Physical Education and Sport 15, (3): 513-522. DOI 10.22190/FUPES1703513S

17. Sports Law, Official Gazette of the Republic of Serbia, no.10/2016.

18. Stanković, T. 2017. Uticaj masovnih medija na popularnost sporta u svetu i kod nas. Fakultet sporta i fizičkog vaspitanja, Beograd.

19. Šurbatović J. 2014. Menadžment u sportu. JP Zavod za udžbenike Beograd.

20. Vukša S., D. Anđelić, i I. Milojević. 2020. Analiza kao osnova održivosti poslovanja. Održivi razvoj 2, (1): 53-72.

\section{PRAVNI ASPEKTI MERČENDAJZINGA U SPORTU}

\section{Mario Lukinoviça , Ana Opačićc ${ }^{10}$, Irena Milojevićc ${ }^{11}$}

\section{Rezime}

Sport je u poslednjih trideset godina pretrpeo značajnu transformaciju od sredstva za zadovoljavanje potrebe za fizičkom aktivnošću, afirmacijom ili takmičenjem sa drugima do izuzetno profitabilne privredne grane. Razvoju sporta pogodovao je razvoj masovnih medija u pogledu kreiranja planetarnih sportskih idola. Potrošači su danas izloženi agresivnoj marketinškoj politici, te prezasićenost informacijama proizvođači pokušavaju da prevaziđu eksploatisanjem prepoznatljivih simbola s kojima potrošači žele da se identifikuju i to putem emocionalnog pozicioniranja proizvoda. Autori u radu ukazuju na značaj mechandisinga kao i svih specifičnosti koje on manifestuje primenom u sportu, sa posebnim osvrtom na pravni okvir $i$ instrumente daljeg prenosa prava i zaštite istih.

Ključne reči: merčendajzing, ustupanje prava, sport, marketing, Srbija.

Datum prijema (Date recieved): 11.02.2020.

Datum prihvatanja (Date accepted): 08.06.2020.

\footnotetext{
${ }^{9}$ prof. dr Mario Lukinovic, Pravni fakultet, Univerzitet Union, Beograd, Srbija

${ }^{10}$ prof. dr Ana Opacic, Fakultet za poslovne studije i pravo, Univerzitet "Union Nikola Tesla", Beograd, Srbija

${ }^{11}$ Irena Milojevic, Institut primenjenih nauka, Lomina 2, Beograd, Srbija
} 